\title{
ENHANCING GROWTH IN EUCOMIS AUTUMNALIS (MILL.) CHITT. SEEDLINGS WITH EXOGENOUS APPLICATION OF NITRIC OXIDE
}

\author{
Short communication \\ Piotr SALACHNA*, Agnieszka ZAWADZIŃSKA, Łukasz WIERZBIŃSKI, \\ Wojciech SENDEREK \\ West Pomeranian University of Technology in Szczecin \\ Papieża Pawła VI 3, 71-459 Szczecin, Poland
}

Received: October 2016; Accepted: December 2016

\begin{abstract}
Nitric oxide (NO) is a molecule that regulates biological processes in plants and may be used in horticultural practice as a potential plant growth regulator. Eucomis autumnalis (Mill.) Chitt., also known as pineapple lily, is a member of the Asparagaceae and native to South Africa. Pineapple lily are well suited for production as pot plants, cut flowers, and garden plants. The potential also exists for this species to be used as a medicinal plant. The aim of the study was to assess the effects of the NO donor of sodium nitroprusside (SNP) on morphological features of E. autumnalis seedlings. The plants grown in a greenhouse were drenched four times, at weekly intervals, with SNP solutions of the following concentration: 0, 100, $200,300,400$, and $500 \mu \mathrm{M}$. The study revealed that the application of SNP significantly improved greenness index of leaves, leaf length, and leaf fresh weight, as compared to the control at all levels. This treatment also showed a significant increase in bulb and root fresh weight, root number, and root length. Application of SNP at $200 \mu \mathrm{M}$ increased the values of the attributes studied to the maximum extent.
\end{abstract}

Key words: growth regulators, flower bulbs, pineapple lily, sodium nitroprusside

\section{INTRODUCTION}

Nitric oxide (NO) is a free radical and a signal molecule that plays an important role in plant signal transduction pathways (Baudouin \& Hancock 2013). NO is present in plant tissues at very low concentrations, and its activity consists in stimulation or inhibition of various physiological and morphogenetic processes and hardening the plants against abiotic stresses (Sanz et al. 2015). The most common nitric-oxide-releasing compound (donor) is sodium nitroprusside (SNP) (Popova \& Tuan 2010). Exogenous application of SNP was shown to break dormancy, stimulate seed germination and root system development, as well as affect growth and flowering (Liao et al. 2010; 2011; Gniazdowska et al. 2012; Niu et al. 2015; Wang et al. 2015; Arun et al. 2016).
Eucomis autumnalis (Mill.) Chitt. is an ornamental bulbous plant with huge potential on the horticultural market. The species belongs to Asparagaceae family and is endemic to South Africa (Zonneveld \& Duncan 2010). E. autumnalis produces a very unusual inflorescence finished with a plume of leaves and comprising numerous whitegreen, sweet-scented flowers. It can also be grown as a pot or garden plant (De Hertogh \& Le Nard 1993). As it produces anti-inflammatory and antispasmodic substances, E. autumnalis has been used in natural medicine for a long time (Zschocke et al. 2000). The main source of biologically active compounds are leaves, roots, and bulbs (Taylor \& van Staden 2001; Masondo et al. 2014; Salachna et al. 2015a) that are collected from natural sites at a massive scale. This results in extinction of entire populations of E. autumnalis. Therefore, efficient methods of 
this species reproduction are sought after (Taylor \& van Staden 2001; Ndhlala et al. 2012; Salachna et al. 2015b). The effects of various growth stimulants are also experimentally tested (Salachna \& Zawadzińska 2015; Aremu et al. 2015; 2016).

To date, there have been no research reports on treating E. autumnalis with nitric oxide, which is why this study investigating the effects of various concentrations of SNP on morphological features of E. autumnalis was undertaken.

\section{MATERIALS AND METHODS}

The seeds of E. autumnalis were collected in the second half of September 2014 from the plants growing on experimental plots of the Department of Horticulture, West Pomeranian University of Technology in Szczecin (53 $25^{\prime} \mathrm{N}, 14^{\circ} 32^{\prime}$ E; 25 m.a.s.l.). Dry seeds were stored in paper bags in darkness at $18-20{ }^{\circ} \mathrm{C}$ (until January 15,2015 ) and then at 4 $5{ }^{\circ} \mathrm{C}$ (60 days). Following stratification, the seeds were disinfected with $50 \%$ ethanol, rinsed in distilled water, and sown into boxes filled with substrate TS 1 with $\mathrm{pH} 5.6$ and $\mathrm{EC} 1.17 \mathrm{mS} \cdot \mathrm{cm}^{-1}$ (Klasmann-Deilmann, Poland). The boxes were placed in a greenhouse with day/night temperature set at $22 / 18{ }^{\circ} \mathrm{C}$. After 13 weeks, the seedlings, in batches of four, were transplanted into round plastic pots with a diameter of $16 \mathrm{~cm}\left(1.7 \mathrm{dm}^{3}\right)$, which is filled with deacidified peat with $\mathrm{pH} 5.5$ and EC $0.23 \mathrm{mS} \cdot \mathrm{cm}^{-1}$ mixed with Yara Mila Complex fertilizer (Yara International ASA, Norway) containing $12 \% \mathrm{~N}, 4.8 \% \mathrm{P}$, and $15 \% \mathrm{~K}$ plus micronutrients, used at $2 \mathrm{~g} \cdot \mathrm{dm}^{-3}$. The pots were placed on a table in the greenhouse under natural photoperiod. SNP (Sigma-Aldrich, India) treatments were initiated 10 days after the transplantation. The plants were drenched with $150 \mathrm{ml}$ per pot of SNP solutions four times, at weekly intervals, at the following concentrations: $0,100,200,300,400$, and $500 \mu \mathrm{M}$ SNP. Control plants were drenched with distilled water. On the last day of the experiment (September 21, 2015), leaf greenness index was determined in SoilPlant Analysis Development (SPAD) units with an optical device Chlorophyll Meter SPAD-502 (Minolta, Japan). The measurements taken included three readings per each leaf. Then, the plants were removed from the pots, rinsed in tap water, and dried. After that, the following parameters were estimated: the number of leaves, length of the longest leaf, width of the longest leaf at its widest point, fresh weight of bulbs and roots, bulb diameter, and number and length of the longest roots. The experiment was designed as a completely randomized with 24 replications ( 6 pots $\times 4$ plants per pot). The results were statistically analyzed by means of univariate analysis of variance and the post-hoc comparison were done using the Duncan multiple range test at $\mathrm{P}=0.05$ using STATISTICA 12.0 software.

\section{RESULTS AND DISCUSSION}

Exogenous application of SNP (a nitric oxide donor) had significant effects on leaf traits of $E$. $a u$ tumnalis seedlings (Table 1). All SNP-treated plants had significantly higher greenness index of leaves up to $15.7-24.0 \%$ compared to the control. Among the different concentrations of SNP, treatment with SNP at 100,200 , and $500 \mu \mathrm{M}$ concentrations had the greatest stimulatory effect on greenness index of leaves. These results are in agreement with those of Hayat et al. (2011) who reported that leaves of tomato plants treated with SNP at all concentrations $\left(10^{-6}, 10^{-5}\right.$, or $\left.10^{-4} \mathrm{M}\right)$ had significantly higher greenness index (SPAD) over their respective controls, and the greatest increase was in leaves of plants from seeds treated with $10^{-5} \mathrm{M}$ of SNP. Also, Beligni and Lamattina (2000) indicated that wheat seedlings sprayed with SNP and grown in darkness contained $30 \%$ to $40 \%$ more chlorophyll than control seedlings. A promotive effect of exogenous NO on chlorophyll content might perhaps be attributed to the role of NO in chlorophyll biosynthesis by enhancement of the conversion of $\mathrm{Mg}$-protoporphyrin to protochlorophyllide and subsequently to chlorophyll (Abdel-Kader 2007).

The number of leaves per plant exhibited a dose-dependent effect to SNP (Table 1). Compared to the non-treated plants (control), the maximal number of leaves was obtained at $200 \mu \mathrm{M}$ of SNP. Furthermore, application of SNP at $200 \mu \mathrm{M}$ increased the leaf length, leaf width, and leaf fresh weight by $61.7 \%, 56.5 \%$, and $308 \%$, respectively (Table 1). 
Table 1. Effect of sodium nitroprusside (SNP) at different concentration on leaf characteristics of Eucomis autumnalis seedlings

\begin{tabular}{cccccc}
\hline $\begin{array}{c}\text { SNP } \\
\text { concentration } \\
(\mu \mathrm{M})\end{array}$ & $\begin{array}{c}\text { Greenness } \\
\text { index of leaves } \\
(\text { SPAD })\end{array}$ & No. of leaves & $\begin{array}{c}\text { Leaf length } \\
(\mathrm{cm})\end{array}$ & $\begin{array}{c}\text { Leaf width } \\
(\mathrm{cm})\end{array}$ & $\begin{array}{c}\text { Leaf fresh } \\
\text { weight } \\
(\mathrm{g})\end{array}$ \\
\hline 0 & $31.2 \pm 2.43 \mathrm{c}^{*}$ & $2.75 \pm 0.75 \mathrm{c}$ & $8.35 \pm 0.87 \mathrm{~d}$ & $1.47 \pm 0.18 \mathrm{~d}$ & $0.50 \pm 0.11 \mathrm{~d}$ \\
100 & $38.5 \pm 1.78 \mathrm{a}$ & $3.08 \pm 0.51 \mathrm{bc}$ & $10.2 \pm 0.65 \mathrm{c}$ & $1.68 \pm 0.15 \mathrm{c}$ & $0.82 \pm 0.14 \mathrm{c}$ \\
200 & $38.7 \pm 1.65 \mathrm{a}$ & $4.08 \pm 0.51 \mathrm{a}$ & $13.5 \pm 1.46 \mathrm{a}$ & $2.30 \pm 0.28 \mathrm{a}$ & $2.04 \pm 0.28 \mathrm{a}$ \\
300 & $37.7 \pm 3.05 \mathrm{ab}$ & $3.41 \pm 0.51 \mathrm{~b}$ & $12.5 \pm 1.48 \mathrm{~b}$ & $1.76 \pm 0.29 \mathrm{bc}$ & $1.24 \pm 0.20 \mathrm{~b}$ \\
400 & $36.1 \pm 2.65 \mathrm{~b}$ & $2.91 \pm 0.79 \mathrm{bc}$ & $11.1 \pm 1.22 \mathrm{c}$ & $1.65 \pm 0.17 \mathrm{~cd}$ & $0.93 \pm 0.25 \mathrm{c}$ \\
500 & $38.5 \pm 1.68 \mathrm{a}$ & $3.25 \pm 0.45 \mathrm{bc}$ & $10.7 \pm 1.46 \mathrm{c}$ & $1.91 \pm 0.29 \mathrm{~b}$ & $0.78 \pm 0.09 \mathrm{c}$ \\
\hline
\end{tabular}

$*$ Values are expressed as means \pm standard deviation $(n=24)$. Values followed by a different letter in the same column were significantly different by Duncan's multiple range test at $\mathrm{P}=0.05$.

Table 2. Effect of sodium nitroprusside (SNP) at different concentration on root and bulb characteristics of Eucomis autumnalis seedlings

\begin{tabular}{clcccc}
\hline $\begin{array}{c}\text { SNP } \\
\text { concentration } \\
(\mu \mathrm{M})\end{array}$ & No. of roots & $\begin{array}{c}\text { Root fresh } \\
\text { weight }(\mathrm{g})\end{array}$ & Root length $(\mathrm{cm})$ & $\begin{array}{c}\text { Bulb fresh } \\
\text { weight }(\mathrm{g})\end{array}$ & $\begin{array}{c}\text { Bulb diameter } \\
(\mathrm{mm})\end{array}$ \\
\hline 0 & $3.91 \pm 0.79 \mathrm{e}^{*}$ & $0.08 \pm 0.00 \mathrm{e}$ & $2.60 \pm 0.24 \mathrm{c}$ & $0.30 \pm 0.03 \mathrm{e}$ & $7.47 \pm 0.45 \mathrm{c}$ \\
100 & $4.91 \pm 0.79 \mathrm{~cd}$ & $0.37 \pm 0.06 \mathrm{~b}$ & $4.87 \pm 0.45 \mathrm{~b}$ & $0.56 \pm 0.08 \mathrm{c}$ & $8.24 \pm 0.42 \mathrm{~b}$ \\
200 & $6.58 \pm 1.16 \mathrm{a}$ & $0.68 \pm 0.11 \mathrm{a}$ & $6.87 \pm 1.10 \mathrm{a}$ & $0.86 \pm 0.06 \mathrm{a}$ & $9.06 \pm 0.46 \mathrm{a}$ \\
300 & $5.58 \pm 0.99 \mathrm{bc}$ & $0.67 \pm 0.08 \mathrm{a}$ & $4.81 \pm 0.51 \mathrm{~b}$ & $0.71 \pm 0.13 \mathrm{~b}$ & $8.49 \pm 0.64 \mathrm{~b}$ \\
400 & $6.16 \pm 0.71 \mathrm{ab}$ & $0.21 \pm 0.05 \mathrm{c}$ & $4.96 \pm 0.61 \mathrm{~b}$ & $0.54 \pm 0.07 \mathrm{c}$ & $8.15 \pm 0.95 \mathrm{~b}$ \\
500 & $4.66 \pm 0.77 \mathrm{~d}$ & $0.14 \pm 0.04 \mathrm{~d}$ & $4.71 \pm 0.62 \mathrm{~b}$ & $0.39 \pm 0.09 \mathrm{~d}$ & $7.54 \pm 0.49 \mathrm{c}$ \\
\hline
\end{tabular}

*Values are expressed as means \pm standard deviation $(n=24)$. Values followed by a different letter in the same column were significantly different by Duncan's multiple range test at $\mathrm{P}=0.05$.

In conformity with these results, An et al. (2005) reported significant enhancement in the length, width, and weight of leaf in maize seedlings as affected by the application of SNP. The authors found that exogenous NO was also able to elevate the activity of glucanases in leaf cell wall.

SNP treatments significantly increased all the examined root parameters of the seedlings compared to the control (Table 2). Of the tested dose of SNP, $200 \mu \mathrm{M}$ proved the best. Compared with the control, the application of SNP at $200 \mu \mathrm{M}$ increased the number of roots, root fresh weight, and root length by $68.3 \%, 750 \%$, and $164 \%$, respectively (Table 2). A similar positive effect of SNP at low concentrations on adventitious root initiation was observed in Chrysanthemum morifolium (Liao et al. 2010), Tagetes erecta (Liao et al. 2011), and Petunia hybrida (Arun et al. 2016). A stronger root system provides faster plant growth and faster production of bulbs of the commercial size, which ensures flowering.

SNP had significant effects on yield of bulb, and the effects were dose dependent (Table 2). From all SNP concentrations, $200 \mu \mathrm{M}$ resulted in the greatest increase in bulb fresh weight and bulb diameter. Application of SNP at $200 \mu \mathrm{M}$ enhanced the bulb fresh weight and bulb diameter by $186 \%$ and $21.3 \%$, respectively, in comparison to the control. These are the first published results that indicate that NO molecules, when applied exogenously, positively improved bulbs yield. This positive effect of NO could be attributed to enhanced leaves and roots parameters (Tables $1 \& 2$ ).

This work strongly argues that the NO donor SNP when applied exogenously improved the 
growth of E. autumnalis seedlings. The effects of SNP was dose dependent, with the highest values of growth attributes response at $200 \mu \mathrm{M}$. All the examined growth parameters enhanced with SNP application might be ascribed to the role of NO in plant growth stimulation in general. However, physiological role of NO on plant growth and pharmacological properties of E. autumnalis is not yet known and will be the subject of future research.

\section{REFERENCES}

Abdel-Kader D.Z.E.-A. 2007. Role of nitric oxide on iron homeostasis, chlorophyll biosynthesis and antioxidants system in two wheat cultivars. American Journal of Plant Physiology 2(4): 237-250. DOI: 10.3923/ajpp.2007.237.250.

An L., Liua Y., Zhang M., Chen T., Wang X. 2005. Effects of nitric oxide on growth of maize seedling leaves in the presence or absence of ultraviolet-B radiation. Journal of Plant Physiology 162(3): 317326. DOI: 10.1016/j.jplph.2004.07.004.

Aremu A.O., Masondo N.A., Rengasamy K.R.R., Amoo S.O., Gruz J., Biba O., et al. 2015. Physiological role of phenolic biostimulants isolated from brown seaweed Ecklonia maxima on plant growth and development. Planta 241(6): 1313-1324. DOI: 10.1007/s00425-015-2256-X.

Aremu A.O., Plačková L., Gruz J., Biba O., Novák O., Stirk W.A., et al. 2016. Seaweed-derived biostimulant (Kelpak $\left.{ }^{\circledR}\right)$ influences endogenous cytokinins and bioactive compounds in hydroponically grown Eucomis autumnalis. Journal of Plant Growth Regulation 35(1): 151-162. DOI: 10.1007/s00344-0159515-8.

Arun M., Radhakrishnan R., Ai T.N., Naing A.H., Lee I.J., Kim C.K. 2016. Nitrogenous compounds enhance the growth of petunia and reprogram biochemical changes against the adverse effect of salinity. The Journal of Horticultural Science and Biotechnology 91(6): $562-572 . \quad$ DOI: 10.1080/14620316.2016.1192961.

Baudouin E., Hancock J.T. 2013. Nitric oxide signaling in plants. Frontiers in Plant Science 4: 553. DOI:10.3389/fpls.2013.00553.

Beligni M.V., Lamattina L. 2000. Nitric oxide stimulates seed germination and de-etiolation, and inhibits hypocotyl elongation, three light-inducible responses in plants. Planta 210(2): 215-221. DOI: 10.1007/PL00008128.
De Hertogh A., Le Nard M. 1993. General chapter on summer flowering bulbs. In: De Hertogh A., Le Nard M. (Eds.). The physiology of flower bulbs. Elsevier Science Publishers, Amsterdam, London, p. 741-774.

Zonneveld B.J.M., Duncan G.D. 2010. Genome sizes of Eucomis L'Hér (Hyacinthaceae) and a description of the new species Eucomis grimshawii G.D.Duncan \& Zonneveld. Plant Systematics and Evolution 284(12): 99-109. DOI: 10.1007/s00606-009-0236-y.

Gniazdowska A., Babańczyk T., Krasuska U. 2012. Nitric oxide as germination controlling factor in seeds of various plant species. Phyton, Annales Rei Botanicae, Horn 52(2): 219-226.

Hayat S., Yadav S., Wani A.S., Irfan M., Ahmad A. 2011. Nitric oxide effects on photosynthetic rate, growth, and antioxidant activity in tomato. International Journal of Vegetable Science 17(4): 333348. DOI: 10.1080/19315260.2011.563275.

Liao W., Huang G., Yu J., Zhang M., Shi X. 2011. Nitric oxide and hydrogen peroxide are involved in indole-3-butyric acid-induced adventitious root development in marigold. The Journal of Horticultural Science and Biotechnology 86(2): 159-165. DOI: $10.1080 / 14620316.2011 .11512742$.

Liao W.-B., Xiao H.-L., Zhang M.-L. 2010. Effect of nitric oxide and hydrogen peroxide on adventitious root development from cuttings of ground-cover chrysanthemum and associated biochemical changes. Journal of Plant Growth Regulation 29(3): 338-348. DOI: 10.1007/s00344-010-9140-5.

Masondo N.A., Finnie J.F., van Staden J. 2014. Pharmacological potential and conservation prospect of the genus Eucomis (Hyacinthaceae) endemic to southern Africa. Journal of Ethnopharmacology 151(1): 44-53. DOI: 10.1016/j.jep.2013.11.002.

Ndhlala A.R., Mulaudzi R.B., Kulkarni M.G., van Staden J. 2012. Effect of environmental factors on seedling growth, bulb development and pharmacological properties of medicinal Eucomis autumnalis. South African Journal of Botany 79: 1-8. DOI: 10.1016/j.sajb.2011.10.008.

Niu L., Li B., Liao W., Zhu Y., Wang M., Jin X., Xu Q. 2015. Effect of nitric oxide on dormancy release in bulbs of Oriental lily (Lilium orientalis) 'Siberia'. The Journal of Horticultural Science and Biotechnology 90(6): 594-598. DOI: 10.1080/14620316.2015.11668720.

Popova L., Tuan T. 2010. Nitric oxide in plants: Properties, biosynthesis and physiological functions. Iranian Journal of Science and Technology, Transaction A, 34(A3): 173-183. 
Salachna P., Zawadzińska A. 2015. Comparison of morphological traits and mineral content in Eucomis autumnalis (Mill.) Chitt. plants obtained from bulbs treated with fungicides and coated with natural polysaccharides. Journal of Ecological Engineering 16(2): 136-142. DOI: 10.12911/22998993/1868.

Salachna P., Grzeszczuk M., Wilas J. 2015a. Total phenolic content, photosynthetic pigment concentration and antioxidant activity of leaves and bulbs of selected Eucomis L'Hér. taxa. Fresenius Environmental Bulletin 24(11c): 4220-4225.

Salachna P., Zawadzińska A., Wilas J. 2015b. The use of natural polysaccharides in Eucomis autumnalis propagation by twin-scale cuttings. Acta Horticulturae 1104: 225-228. DOI: 10.17660/ActaHortic.2015.1104.34.

Sanz L., Albertos P., I., Mateos I., Sánchez-Vicente I., Lechón T., Fernández-Marcos M., Lorenzo O. 2015. Nitric oxide (NO) and phytohormones cross- talk during early plant development. Journal of Experimental Botany 66(10): 2857-2868. DOI: 10.1093/jxb/erv213.

Taylor J.L.S., van Staden J. 2001. The effect of nitrogen and sucrose concentrations on the growth of Eucomis autumnalis (Mill.) Chitt. plantlets in vitro, and on subsequent anti-inflammatory activity in extracts prepared from the plantlets. Plant Growth Regulation 34(1): 49-56. DOI: 10.1023/A:1013303624296.

Wang M., Li B., Zhu Y.-C., Niu L.-J., Jin X., Xu Q.-Q., Liao W.-B. 2015. Effect of exogenous nitric oxide on vegetative and reproductive growth of oriental lily 'Siberia'. Horticulture, Environment, and Biotechnology. 56(5): 677-686. DOI: 10.1007/s13580-015-0051-z.

Zschocke S., Rabe T., Taylor J.L.S., Jäger A.K., van Staden J. 2000. Plant part substitution - a way to conserve endangered medicinal plants? Journal of Ethnopharmacology 71(1-2): 281-292. DOI: 10.1016/S0378-8741(00)00186-0. 